\title{
Strategi Pengembangan Obyek Wisata Di Wilayah Makam Bung Karno Kota Blitar
}

\author{
Agus Zainal Arifin \\ Magister Manajemen Universitas Islam Kadiri \\ Email: zainalagusarifin12@gmail.com
}

\begin{abstract}
This research is a type of descriptive research with qualitative research methods. So that this method can describe and analyze the swot strategy for increasing the competitiveness of the development of regional tourism in the City of Blitar (Settlement of Tourism Supporters as an Effort to Increase Competitiveness in the Development of Tourism Objects of Bung Karno's Tomb of Blitar City) The implementation of this method is not limited to data collection and preparation, but also includes analysis and interpretation of the data. Data analysis techniques used are descriptive analysis techniques with data reduction steps, and conclusion drawing.

The results showed that the Research on Housing and Settlement Area Development Plans in the Jatimalang Embankment and Bendung Tanggung Areas was the development of tourism-based housing and settlements. In the sense that there has been a mutually beneficial collaboration including, both residential and residential areas and tourism areas, in this case the concept of the need to establish regional management institutions for Tourism Settlement Settlement as an Effort to Increase Competitiveness in the Development of Tourism Objects of the Bung Karno Tomb of Blitar City which is a joint representation for all residents of Kepanjenkidul Subdistrict, especially the Sentul Village and the City of Blitar.
\end{abstract}

Keywords: Settlement of Settlements, Tourism Objects, Competitiveness, Development

\section{A. Latar Belakang Teoritis}

Perencanaan merupakan tahapan pertama dalam kegiatan apapun termasuk program kerja pemerintah. Tahap ini menentukan suatu rangkaian kerja yang menyeluruh. Apabila perencanaan berhasil, maka sama artinya dengan merencanakan keberhasilan, sebaliknya bila gagal maka sama artinya dengan merencanakan kegagalan. Sehingga alat analisis dalam perencanaan menjadi bagian penentu dalam keberhasilan perencanaan.

Perencanaan strategis bukan merupakan hasil atau keluaran melainkan suatu proses yang terus berlangsung. Pemikiran strategis tidak memiliki titik akhir, dan akibatnya proses perencanaan berlangsung terus menerus. Salah satu dari proses manajemen strategis adalah mengenali lingkungan internal perusahaan (StrengthWeakness) dan lingkungan eksternal perusahaan (Oppurtunity-Threat) (Zimmerer,2002:37).

Perubahan besar terjadi di bidang pemerintahan sejak diberlakukannya UndangUndang tentang Otonomi yang antara lain Undang-Undang Nomor 22 Tahun 1999 tentang Pemerintah Daerah. UndangUndang tersebut sebagai pengganti Undang-
Undang Nomor 5'Tahun 1974 tentang Pemerintahan Desa dan Undang-undang Nomor 5Tahun 1974 tentang Pokok-pokok Pemerintahan di Daerah, yang kemudian disempurnakan dengan Undang-Undang Nomor 32 Tahun2004 dan Undang-Undang Nomor $\quad 12 \quad$ Tahun 2008. PelaksanaanUndang-undang ini membawa konsekuensi daerah harus mampu mengembangkan Otonomi Daerah secara luas, nyata dan bertanggung jawab dalam rangka pemberdayaan masyarakat. Juga dituntut melakukan berbagai upaya kreatif sesuai dengan kewenangannya dengan berpedoman peraturan dan perundangan yang berlaku.

Kota Blitar secara umum tidak memiliki sumberdaya alam yang melimpah untuk dijadikan sumber pendapatan daerah.Oleh karena itu salah satu upaya pemerintah untuk meningkatkan pendapatan daerah yaitu dengan mengembangkan sektor pariwisata. Kota Blitar merupakan salah satu daerah tujuan wisata (DTW) di Jawa Timur karena memiliki keunikan budaya dan keindahan alam sebagai asset wisata yang mampu menarik minat wisatawan untuk berkunjung ke daerah ini.

Pengembangan wilayah dalam bentuk penambahan luasan wilayah sudah 
tidak memungkinkan. Namun demikian, potensi pengembangan wilayah bagi Kota Blitar dapat diartikan dengan pengembangan kemampuan wilayah. Hal ini mengingat dengan terus meningkatnya jumlah penduduk, dan semakin banyaknya jenis kegiatan usaha baik dari segi perdagangan dan jasa, maupun industri pengolahan, akan menimbulkan tuntutan pengembangan wilayah yang juga semakin besar. Dorongan terhadap pengembangan wilayah tersebut merupakan bentuk-bentuk tuntutan dari kebutuhan masyarakat terhadap pemenuhan pelayanan baik dari sektor pendidikan, kesehatan, industri, perdagangan dan jasa, komunikasi serta berbagai bentuk tuntutan pelayanan yang lainnya . Karena keterbatasan lahan, Kota Blitar tidak memiliki potensi sumber daya alam yang memadai. Penggerak ekonomi Kota Blitar tidak dari sektor primer, tetapi sektor tersier terutama perdagangan barang dan jasa sehingga pengembangan wilayah diarahkan pada pengembangan kawasan wisata dan kawasan perdagangan barang dan jasa. Potensi pengembangan wisata Kota Blitar relatif besar dengan keberadaan Makam Bung Karno sebagai icon wisata Kota Blitar. Setiap tahun banyak wisatawan yang mengunjungi Kota Blitar terutama untuk mengunjungi makam Bung Karno.

Makam Bung Karno selalu ramai dari kunjungan wisatawan, baik lokal maupun mancanegara. Selain itu dalam object wisata ini terdapat lapak lapak pedagang yang menjual oleh oleh khas Kota Blitar. Ditunjang dengan sistim pemerintah yang melakukan perekrutan pengayuh becak untuk menghantarkan wisatawan berkeliling object wisata. Pengayuh becak ini hanya dapat dijumpai di kompleks wisata Makam Bung Karno saja, sehingga membentuk suatu komunitas tersendiri berkerjasama dengan pemerintah kota.

Akan tetapi, peningkatan pendapatan selama initidak diperoleh dari retribusi pengunjung. Para peziarah memang tidak dipungutretribusi untuk masuk ke kompleks makam. Sejak seperempat abad lalu, tepat sewindu setelah Ir. Soekarno wafat dan dimakamkan di sana, 21 Juni 1970, kompleks makam dipugar. Dengan pemugaran itu pencitraan Makam Bung Karno sebagai ikon Kota Blitar semakin dikukuhkan.Peningkatan pendapatandiproyeksikan terjadi dengan menggerakkan serta merangsang perekonomianmasyarakat, terutama di sekitar kompleks makam.

Lebih lanjut, dalam rencana pembangunan Kota Blitar, khususnya bidang pariwisata, Makam Bung Karno memang diarahkan sebagai pionir seluruh pembangunan obyek wisata di kawasan itu. Lebih jauh lagi, Pemkot Blitar juga merencanakan agar obyek-obyek pariwisata unggulan itu bisa mengangkat dan menghidupkan sektor industri kecil dan kerajinan di sekelilingnya.

Dalam upaya membangun iklim yang kondusif sebagai kota Patria yang didukung oleh sistem perdagangan barang dan jasa unggulan, pemerintah Kota Blitar memilih sektor pariwisata sebagai primadona untuk mengembangkan ekonomi daerah. Beberapa tempat tujuan wisata yang ada di Blitar, dibenahi dan diperkaya guna meningkatkan potensi wisata di Kota Blitar. Untuk itu, pemerintah merencanakan kawasan pemukiman penunjang wisata makam Bung Karno.

Kota Blitar merupakan sebuah kota yang mengandalkan sektor kepariwisataan. Pengembangan kawasan pariwisata di Kota Blitar lebih berorientasi pada perkembangan kawasan pariwisata budaya dan buatan. Hal ini dikarenakan kondisi alam Kota Blitar yang memang tidak memiliki kawasan wisata alam yang menarik. Sedangkan untuk wisata budaya dan buatan sudah mencukupi kebutuhan untuk wilayah dan penduduk Kota Blitar yang tidak terlalu besar. Dengan demikian pemasaran kawasan pariwisata Kota Blitar mulai diarahkan untuk pemasaran yang terintegrasi dengan daerah lain di luar Kota Blitar. Pembagian kawasan pariwisata di Kota Blitar adalah berupa kawasan Pariwisata Budaya terutama kawasan wisata Makam Bung Karno dan Kawasan Pariwisata Buatan (Alun-Alun Kota, Waterpark Sumber Udel, Hutan Kebun Rojo, Taman Pecut dan lain-lain ). Arah dan kebijakan kepariwisataan di Kota Blitar tertuang dalam dokuman RIPPDA Kota Blitar.

Permukiman Pendukung Kawasan Wisata di Kota Blitar ini diharapkan dapat memberikan arahan/pengendalian tahapan pembangunan di kawasan permukiman di sekitar Jatimalang dan Kelurahan Tanggung 
Kota Blitar, sehingga perencanaan pembangunan yang dihasilkan pada akhirnya dapat mewujudkan kesejahteraan bagi masyarakat Kota Blitar.

Hal ini sejalan dengan tujuan jangka panjang yang ingin dicapai Kota Blitar seperti termaktub dalam RPJP Kota Blitar tahun 2005 - 2025 dalam misi pertamanya "menguatkan predikat Kota Blitar sebagai Kota Pariwisata Sejarah" dengan arah kebijakan mereaktualisasikan predikat Kota Blitar sebagai laboratorium kebangsaan dan pusat penumbuhkembangan kembali semangat nasionalisme Indonesia serta merevitalisasi pengelolaan pariwisata daerah melalui pengembangan obyek wisata daerah di Kota Blitar. Tujuan Penelitian

\section{Pengertian Permukiman}

Pengertian permukiman menurut kamus besar Indonesia (1989; 569) adalah daerah tempat penduduk bermukim. Sedangkan pengertian permukiman berdasarkan Undang - Undang Nomor 4 Tahun 1992 tentang perumahan dan permukiman adalah bagian dari lingkungan hidup diluar kawasan lindung, baik berupa kawasan perkotaan maupun kawasan pedesaan yang berfungsi sebagai lingkungan tempat tinggal atau lingkungan hunian dan tempat kegiatan yang mendukung perikehidupan dan penghidupan.

Kata permukiman merupakan sebuah istilah yang terdiri atas dua kata yang mempunyai arti yang berbeda, yaitu (a) Isi, mempunyai implementasi yang menunjuk kepada manusia sebagai penghuni maupun masyarakat di lingkungan sekitarnya. (b) Wadah, menunjukkan fisik hunian terdiri dari alam dan elemen buatan manusia

Program penataan permukiman yang dilakukan oleh pemerintah sebagai salah satu bagian dari kebijaksanaan dalam menanggulangi masalah-masalah permukiman bertujuan untuk (a) Memenuhi kebutuhan rumah sebagai salah satu kebutuhan kebutuhan dasar manusia dalam rangka peningkatan dan pemerataan kesejahteraan rakyat. (b) Mewujudkan perumahan dan permukiman yang layak dalam lingkungan yang sehat, aman, serasi dan teratur. (c) Memberi arah pertumbuhan wilayah dan persebaran penduduk yang rasional. (d) Mewujudkan rumah yang layak dalam lingkungan yang aman, sehat, dan teratur. (e) Memberi arah panduan mewujudkan perumahan dan permukiman yang merupakan kebutuhan dasar manusia dalam rangka pemerataan permukiman dan sarana umum, ditinjau pula dari beberapa hal antara lain, hanya beberapa rumah terletak di gang-gang dan sepanjang aliran sungai pola rumahnya tidak teratur.

\section{Faktor dalam Permukiman}

Agar terciptanya tertib pembangunan permukiman, terdapat lima faktor utama yang saling berkaitan dan harus dijadikan pokok perhatian, yaitu (Doxiadis dalam Budihardjo, 1995:52-54):

a. Alam, menyangkut tentang pola tata guna tanah, pemanfaatan dan pelestarian sumber daya alam, daya dukung lingkungan serta taman, area rekreasi atau olahraga.

b. Manusia, antara lain menyangkut tentang pemenuhan kebutuhan fisik atau fisiologis, penciptaan rasa aman dan terlindung, rasa memiliki lingkungan (handarbeni) serta tata nilai dan estetika.

c. Masyarakat, menyangkut tentang partisipasi penduduk, aspek hukum, pola kebudayaan, aspek sosial ekonomi, dan kependudukan.

d. Wadah atau sarana kegiatan, menyangkut tentang perumahan, pelayanan umum dan fasilitas umum.

e. Jaringan prasarana, menyangkut utilitas, transportasi dan komunikasi

\section{Aspek dalam permukiman}

Suatu permukiman hendaknya mengikuti kriteria bagi permukiman yang baik, dengan memenuhi hal-hal berikut (Silas, Johan;1990):

a. Aspek fisik, meliputi:

1) Letak Geografis, yaitu aspek yang menentukan keberhasilan dan perkembangan dari suatu kawasan.

2) Lingkungan alam dan binaan, yaitu aspek lingkungan alam dan binaan yang akan sangat mempengaruhi kondisi permukiman serta kehidupan penghuninya.

3) Sarana dan prasarana lingkungan, yaitu penyediaan sarana dan prasarana akan mendukung kegiatan dan kehidupan masyarakat dalam permukiman tersebut. 
b. Aspek non fisik, meliputi:

1) Aspek politik, yang termasuk kebijaksanaan yang mengatur kawasan permukiman, keberadaan lembagalembaga desa dan sebagainya.

2) Aspek ekonomi, yaitu aspek yang meliputi kegiatan yang berkaitan dengan mata pencaharian masyarakat.

3) Aspek sosial, yaitu aspek yang meliputi kehidupan sosial masyarakat, bertetangga dan sebagainya.

4) Aspek budaya, yaitu aspek yang berkaitan dengan kehidupan adat istiadat, kehidupan beragama dan kebiasaan bekerja.

\section{Daya Saing Obyek Wisata}

Konsep daya saing dalam konteks destinasi wisata dikembangkan dari disiplin ilmu manajemen dan pemasaran perusahaan.Daya saing menurut Porter (1995) dapat didefinisikan sebagai kemampuan usaha suatu perusahaan dalam industri untuk menghadapi berbagai lingkungan yang dihadapi. Daya saing pariwisata untuk sebuah destinasi didefinisikan oleh Dupeyras \& MacCallum (2013) sebagai kemampuan tempat untuk mengoptimalkan daya tarik yang berkualitas, inovatif dan menarik bagi masyarakat setempat maupun pengunjung.

Ritchie \& Crouch

mendefinisikan daya saing destinasi sebagai kemampuan suatu destinasi wisata untuk meningkatkan jumlah pengunjung, meningkatkan kesejahteraan masyarakat setempat sekaligus melestarikan sumber daya alam untuk generasi mendatang.

Model Daya Saing Destinasi Wisata Dwyer dan Kim (2003), Model daya saing destinasi wisata ini membawa elemen utama daya saing nasional dan perusahaan seperti yang telah diusulkan dalam literatur yang lebih luas oleh berbagai peneliti pariwisata, Crouch dan Ritchie pada khususnya. Model yang diusulkan mengandung banyak variabel yang telah diidentifikasi oleh Crouch dan Ritchie $(1995,1999)$ dan Ritchie dan Crouch (1993, 2000) dalam kerangka daya saing destinasi wisata komprehensif mereka, tetapi terdapat beberapa perbedaan dari dua model tersebut.

Model Dwyer secara eksplisit mengakui faktor permintaan sebagai salah satu faktor penentu dari daya saing destinasi. a. Sumber Daya Inti (Core Resources), yang terdiri dari sumber daya alami dan buatan.

b. Sumber Daya Pendukung (Suppporting Factor, \& Resources), yang meliputi infrastruktur umum, kualitas layanan, aksesibilitas, keramahan, serta hubungan pasar.

c. Manajemen Destinasi (Destination Management), kategori ini meliputi kegiatan manajemen organisasi destinasi, manajemen pemasaran destinasi, kebijakan destinasi, perencanaan dan pengembangan, pengembangan kualitas sumber daya manusia dan manajemen lingkungan.

d. Faktor Permintaan (Demand Factors), kategori ini terdiri dari tiga unsur utama permintaan pariwisata, yaitu kesadaran, persepsi dan preferensi.

e. Kondisi Situasional (Situational Conditions), Kategori ini meliputi lokasi destinasi wisata, persaingan (mikro), persaingan global, persaingan harga, serta keselamatan dan keamanan.

Tujuan penelitian ini adalah untuk (1) Mendeskripsikan perencanaan peningkatan daya saing pengembangan obyek wisata daerah di Kota Blitar (2) Menganalisis meningkatkan daya saing pada pengembangan obyek wisata Makam Bung Karno Kota Blitar.

\section{B. Metodologi Penelitian Desain Penelitian}

Variabel dalam penelitian ini adalah yang menjadi objek pengamatan penelitian atau merupakan faktor-faktor yang berperan dalam peristiwa atau gejala yang diteliti, dalam hal ini adalah peningkatan daya saing pengembangan obyek wisata daerah di Kota Blitar. Didalam variabel perencanaan peningkatan daya saing pengembangan obyek wisata menurut model Edwards, terdapat beberapa indikator yang dapat digunakan untuk melihat bagaimana proses dan hasil implementasi pengembangan obyek wisata daerah di Kota Blitar, yaitu kontribusi instansi, komitmen instansi, kesiapan instansi, kompetensi instansi, finansial pemerintah, kontrol pemerintah, ketepatan dan kesiapan sasaran. 
Penelitian merupakan suatu kegiatan yang bertujuan untuk memperoleh kebenaran pengetahuan yang bersifat ilmiah, melalui prosedur yang telah ditetapkan. Penelitian hendaknya dilakukan dengan cermat dan teliti, agar hasil yang diperoleh tepat dalam penelitian kegiatan-kegiatan yang dilakukan dengan seksama dalam menentukan jenis data, sumber data, cara mengumpulkan data, tujuan penelitian dan teknik analisa data.

Ada 3 (tiga) persyaratan penting dalam mengadakan kegiatan penelitian menurut Arikunto (1993) yaitu : "Sistematis, berencana dan mengikuti konsep ilmiah. (1) Sistematis artinya dilaksanakan menurut pola tertentu, dari yang paling sederhana sampai kompleks hingga mencapai tujuan secara efektif dan efisien. (2) Berencana artinya direncanakan dengan adanya unsur kesengajaan dan sebelumnya sudah dipikirkan langkah-langkah sebelumnya. (3) Mengikuti konsep ilmiah artinya mulai awal sampai akhir kegiatan penelitian mengikuti cara-cara yang sudah ditentukan, yaitu prinsip memperoleh ilmu pengetahuan"

Penelitian ini merupakan jenis penelitian deskriptif dengan metode penelitian kualitatif.Sehingga dengan metode ini dapat mendeskripsikan serta menganalisa swot strategi peningkatan daya saing pengembangan obyek wisata daerah di Kota Blitar (Penataan Kawasan Permukiman Pendukung Kawasan Wisata Bung Karno)

Dalam penelitian ini jenis penelitian yang digunakan adalah pendekatan deskriptif kualitatif, yaitu dimaksudkan untuk pengukuran yang cermat terhadap fenomena sosial tertentu (Singarimbun dan Effendi, 1989). Peneliti mengembangkan konsep dan menghimpun fakta, tetapi tidak melakukan pengujian hipotesa. Sedangkan menurut Sugiono Penelitian deskriptif adalah penelitian yang dilakukan terhadap variabel mandiri, yaitu tanpa membuat perbandingan atau menghubungkan dengan variabel yang lain.

Menurut Surakhmad, penyelidikan deskriptif ditujukan kepada pemecahan masalah yang ada pada masa sekarang. Sedangkan metode deskriptif kwalitatif menurut Bogman dan Taylor yang dikutip Moleong didefenisikan sebagai prosedur penelitian yang menghasilkan data diskriptif berupa kata-kata tertulis / lisan dari orangorang dan prilaku yang dapat dicermati. Sedangkan oleh Simon dalam Surachmad, mengatakan bahwa metode penelitian deskriptif digunakan untuk mendapatkan deskripsi holistik objek penelitian secara akurat.

Sedangkan Ary et al menyatakan bahwa kualitativedescriptive research aim is to describe "what exist" with respect to variables in or conditions in a situations " atau penelitian deskriptif kualitatif bertujuan unuk mendiskripsikan variabel atau kondisi apa yang ada pada situasi tertentu.

\section{Populasi dan Sampling}

Objek dalam penelitian ini adalah Dinas Perumahan Rakyat Kota Blitar dan masyarakat di kawasan wisata Kota Blitar. Teknik pengumpulan sampel yang peneliti gunakan adalah Stratified Random Sampling. Menurut Nazir (2005 : 277) adalah populasi dibagi dalam kelompok yang homogen lebih dahulu, atau dalam strata. Anggota sampel ditarik dari setiap strata. Jika tidak semua strata ditarik sampelnya, maka ia menjadi multiple stage sampling.

\section{Metode Pengumpulan Data}

Metode penentuan daerah penelitian di Kota Blitar dengan metode purposive (sengaja). Penelitian ini dilakukan pada Satuan Kerja Dinas Perumahan Rakyat Kota Blitar. Adapun data yang diperlukan meliputi data sekunder dan data primer yang diperoleh dengan berbagai cara antara lain : (1) Dokumentasi (2) Wawancara (Indept Interview)

(3) Observasi

\section{Metode Analisa Data Penelitian}

Analisis Data Kualitatif (Bogdan \& Biklen, 1982) dalam Moleong adalah upaya yang dilakukan dengan jalan bekerja data, mengorganisasikan data, memilah-milahnya menjadi satuan yang dapat dikelola, mensintesiskannya, mencari dan menemukan apa yang penting dan apa yang dipelajari, dan memutuskan apa yang dapat diceritakan kepada orang lain

Sedangkan analisis data menurut Patton adalah proses mengatur urutan data, mengorganisasikannya ke dalam suatu pola, kategori, dan satuan uraian dasar. Ia membedakannya dengan penafsiran, yaitu memberikan arti yang signifikan terhadap hasil analisis, menjelaskan pola uraian, dan 
mencari hubungan di antara dimensi-dimensi uraian

Proses analisis data telah mulai sejak merumuskan dan menjelaskan masalah, sebelum terjun ke lapangan, dan berlangsung terus sampai penulisan hasil penelitian. Analisis menjadi pegangan bagi penelitian selanjutnya sampai jika mungkin, teori yang grounded. Analisis data kualitatif berlangsung selama proses pengumpulan data dari pada setelah selesai pengumpulan data.

\section{Lokasi dan Waktu Penelitian}

Populasi dalam penelitian ini adalah

Dinas Perumahan Rakyat Kota Blitar, Instansi Terkait dan masyarakat di kawasan wisata Kota Blitar yaitu Kawasan perencanaan Permukiman Pendukung Kawasan Wisata Makam Bung Karno di arahkan pada kawasan di Kelurahan Sentul dan Kelurahan Tanggung Kecamatan Kepanjen kidul Kota Blitar dan Kawasan di sekitar Embung Jatimalang dan Tanggung.

Waktu penelitian dimulai pada bulan Mei sampai dengan September 2018.

\section{Jenis dan Sumber Data}

Jenis data yang digunakan dalam penlitian ini adalah data kualitatif dan data kuantitatif. Data kualitatif yang disajikan dalam bentuk kata verbal dalam penelitian ini berupa gambaran umum obyek penelitian. Data kuantitatif yang disajikan dalam bentuk angka dapat diukur berupa jumlah sarana dan prasarana, Jumlah Tanggapan terhadap Wisatawan dan Jumlah Tanggapan terhadap Masyarakat Lokal.

Adapun data yang diperlukan meliputi data sekunder(data penelitian yang diperoleh melalui media perantara atau secara tidak langsung yang berupa buku, catatan, bukti yang telah ada, atau arsip baik yang dipublikasikan maupun yang tidak dipublikasikan secara umum) dan data primer (data penelitian yang diperoleh secara langsung dari sumber aslinya yang berupa wawancara, jajak pendapat dari individu atau kelompok (orang).

\section{Metode Pengumpulan Data}

Metode penentuan daerah penelitian di Kota Blitar dengan metode purposive (sengaja). Penelitian ini dilakukan pada Satuan Kerja Dinas Perumahan Rakyat Kota
Blitar. Adapun data yang diperlukan meliputi data sekunder dan data primer yang diperoleh dengan berbagai cara antara lain : Dokumentasi, Wawancara (Indept Interview), Observasi dan Studi Pustaka

\section{Metode Analisa Data}

Analisis Data Kualitatif (Bogdan \& Biklen, 1982) dalam Moleong adalah upaya yang dilakukan dengan jalan bekerja data, mengorganisasikan data, memilah-milahnya menjadi satuan yang dapat dikelola, mensintesiskannya, mencari dan menemukan apa yang penting dan apa yang dipelajari, dan memutuskan apa yang dapat diceritakan kepada orang lain

Sedangkan analisis data menurut Patton adalah proses mengatur urutan data, mengorganisasikannya ke dalam suatu pola, kategori, dan satuan uraian dasar. Ia membedakannya dengan penafsiran, yaitu memberikan arti yang signifikan terhadap hasil analisis, menjelaskan pola uraian, dan mencari hubungan di antara dimensi-dimensi uraian

Proses analisis data telah mulai sejak merumuskan dan menjelaskan masalah, sebelum terjun ke lapangan, dan berlangsung terus sampai penulisan hasil penelitian. Analisis menjadi pegangan bagi penelitian selanjutnya sampai jika mungkin, teori yang grounded. Analisis data kualitatif berlangsung selama proses pengumpulan data dari pada setelah selesai pengumpulan data.

\section{Hasil Dan Implikasi \\ Gambaran Kawasan Perumahan Dan Permukiman Di Blitar}

Dibawah ini akan dijelaskan gambaran umum perumahan dan permukiman di kota Blitar karena permukiman dan perumahan menjadi substansi utama dalam tema perencanaan selain pariwisata. Kedua substansi akan berkolaborasi membentuk hubungan sinergis untuk mengolah potensi yang diunggulkan di kawasan Kelurahan Sentul dan Tanggul, antara lain embung Jatimalang, proyek Bendung Tanggul di Kota Blitar dan kerajinan bubut kayu, dan pembuatan ketipung / alat musik.Potensi kawasan di Kelurahan Sentul Kecamatan Kepanjenkidul adalah sebagai pengrajin kayu dengan produk utamanya ketipung / alat musik. 
Gambaran umum kawasan perumahan dan permukiman di kota Blitar menurut dokumen RP4D Kota Blitar terbagi menjadi :

A. Sebaran Permukiman Berdasarkan Pengadaannya

Berdasarkan pengadaannya, perumahan dan permukiman di Kota Blitar dibagi atas 2 tipe, yaitu: (1) Permukiman swadayaBerupa rumah permanen, semi permanen maupun non permanen (2) Perumahan formaljenis perumahan ini persebarannya terdapat di wilayah perencanaan BWK III Kota Blitar, yaitu di Kelurahan Gedog, Kelurahan Sananwetan, dan Kelurahan Plosokerep.

B. Sebaran Permukiman Berdasarkan Pemanfaatannya/Fungsinya

Berdasarkan pemanfaatannya/fungsinya, perumahan dan permukiman di Kota Blitar dibagi atas 2 jenis, yaitu fungsi khusus hunian dan fungsi campuran/mix used (yaitu untuk hunian sekaligus tempat usaha).

C. Sebaran Permukiman Berdasarkan Status Tanahnya Dan Status kepemilikan Bangunan

Sedangkan kategori permukiman berdasarkan satus kepemilikan bangunan hunian dibagi 3 jenis, yaitu: milik sendiri, sewa, kontrak/indekos, dan lainnya (pinjam atau hanya menempati.)

Selain itu juga diidentifikasikan

beberapa kawasan permukiman khusus di

Kota Blitar, antara lain (mengacu pada

dokument RPKPP Kota Blitar) :

Permukiman di Bantaran Sungai, Permukiman Liar (Squatters), Permukiman di Kawasan Industri Kerajinan Kendang dan Papan Catur, Permukiman di Kawasan Bersejarah, Permukiman di Kawasan Rawan Bencana

$$
\text { Berdasarkan kajian dari }
$$
penyusunan RPKPP di Kota Blitar tahun
2011, dijelaskan bahwa terdapat 9 (sembilan) tipe permukiman di Kota Blitar berdasarkan dokumen SPPIP Kota Blitar. Ke sembilan type permukiman tersebut adalah : Permukiman Developer, Permukiman Padat, Permukiman Kawasan Produktif, Permukiman Lama, Permukiman Rawan Bencana, Permukiman Pinggir Kota, Permukiman Umum, Permukiman di sekitar fasilitas umum, Permukiman dekat kawasan khusus.

\section{Gambaran Kawasan Embung Jatimalang dan Bendung Tanggung}

Kawasan embung yang akan ditata kerkait dengan kepariwisataan di Kota Blitar berada di Kelurahan Sentul dan Tanggung Kecamatan Kepanjenkidul Kota Blitar. Untuk lokasi di Kelurahan Sentul berada di Embung Jatimalang tepatnya di aliran Kali Tanen Dukuh Jatimalang Desa Sentul Kecamatan Kepanjenkidul.

Sedangkan lokasi di Desa Tanggung merupakan revitasisasi DAM dan berada di Sungai / Kali Lahar di Kelurahan Tanggung. Keduanya merupakan kawasan permukiman yang saling berdekatan dan dituntut untuk saling berkolaborasi dan sinergis karena memiliki potensi kepariwisataan.

Dari Laporan Akhir Pekerjaan Survey Investigasi Desain (SID) Embung di Kabupaten Blitar tahun 2015 disebutkan bahwa lokasi embung tersebut termasuk lokasi embung di Kota Blitar, yang kesemuanya berada dalam kewenangan Satker Balai Besar Wilayah Sungai Brantas. Untuk kawasan embung di wilayah Kota Blitar adalah Embung Jatimalang di Desa Sentul. Dalam penyusunan Perencanaan Kawasan Permukiman Pendukung Kawasan Wisata di Kota Blitar, kewenangan berada di Dinas Perumahan Rakyat dan Permukiman Kota Blitar. Lokasi perencanaan ditambahkan dengan lokasi revitalisasi DAM di Desa Tanggung, karena keduanya berdekatan. 

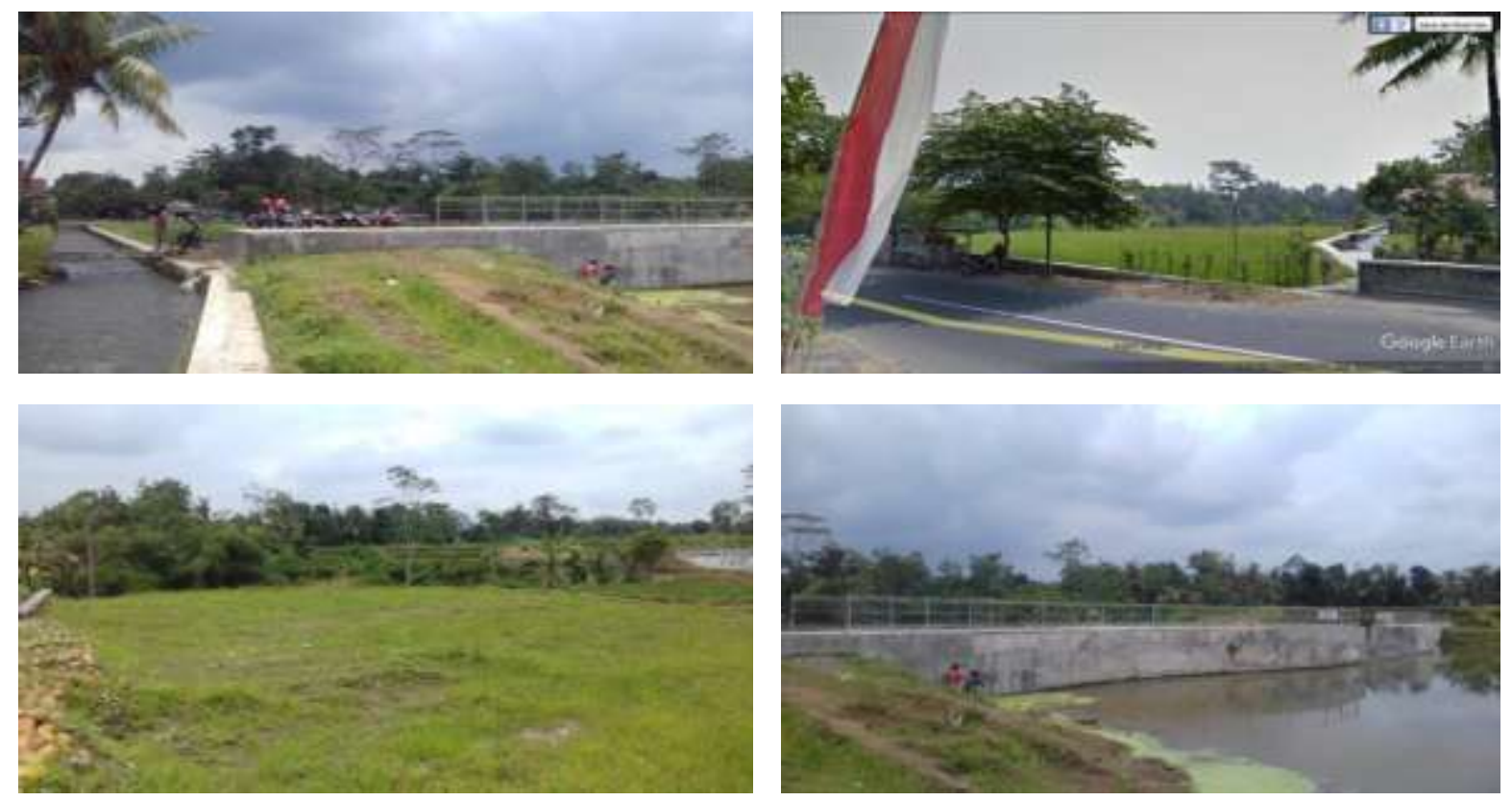

Gambar 1 : Kondisi Eksisting Embung Jatimalang di Kelurahan Sentul di KotaBlitar Sedangkan Kawasan Bendung / Dam Tanggung di Kelurahan Tanggung berada di sekitar sungai Lahar yang melintasi Kelurahan Tanggung. Dari arah J1 Sawunggaling, lokasi Bendung Tanggung berbelok ke kiri ke arah Jl Ciliwung, kemudian berbelok ke kiri menuju ke Jl Cikao. Bendung Tanggung berada di sekitar Sungai Lahar, yang merupakan terusan dari Jl Cikao tersebut.
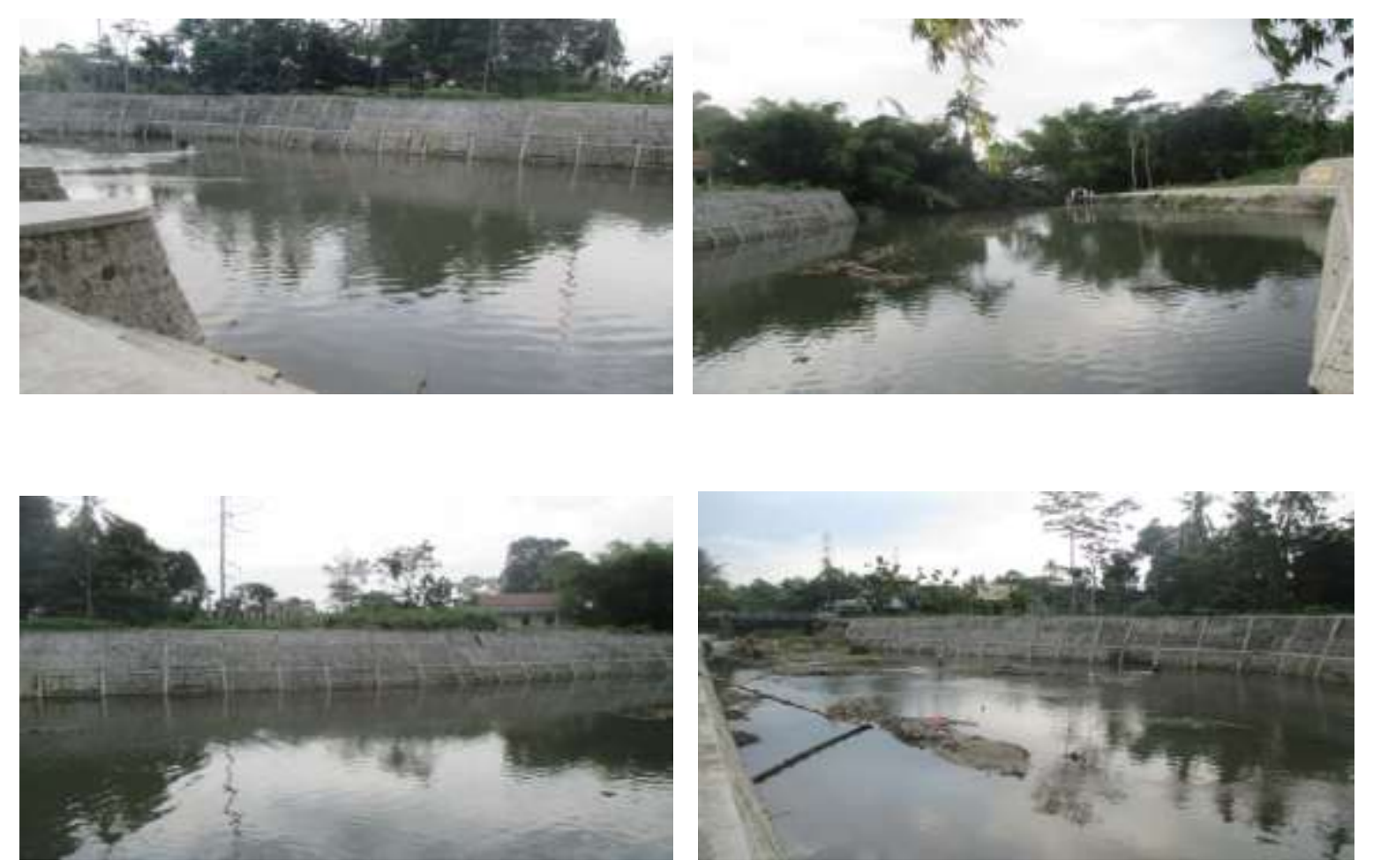

Gambar 2 : Kondisi Eksisting DAM Tanggung di Kelurahan Tanggung - KotaBlitar

Gambar 3 : Konsep Tema Wisata Keluarga di Embung Jatimalang dan Bendung Tanggung

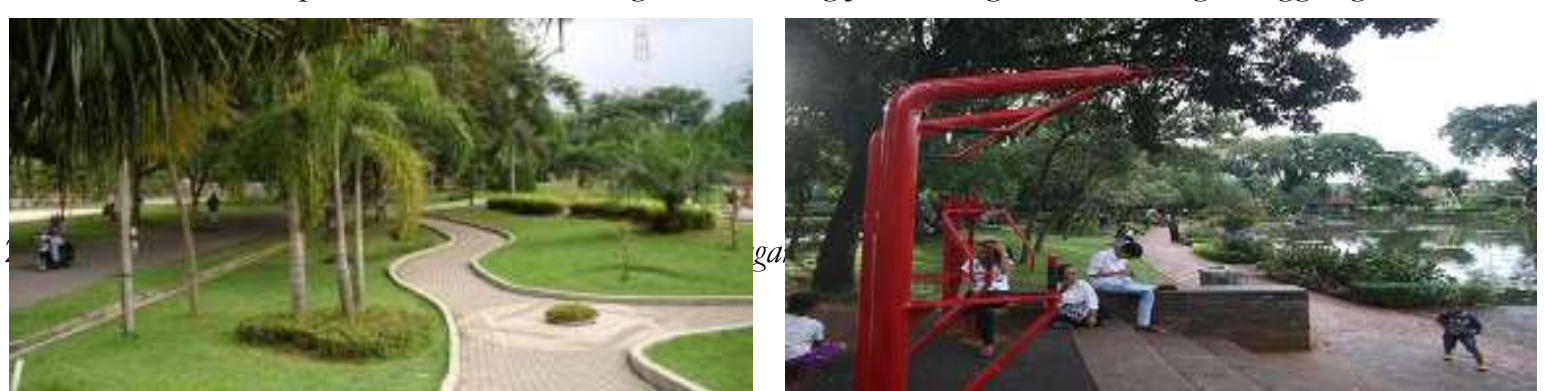


Gambar 4 : RTH dengan Konsep Tema Wisata Keluarga dan Play Ground
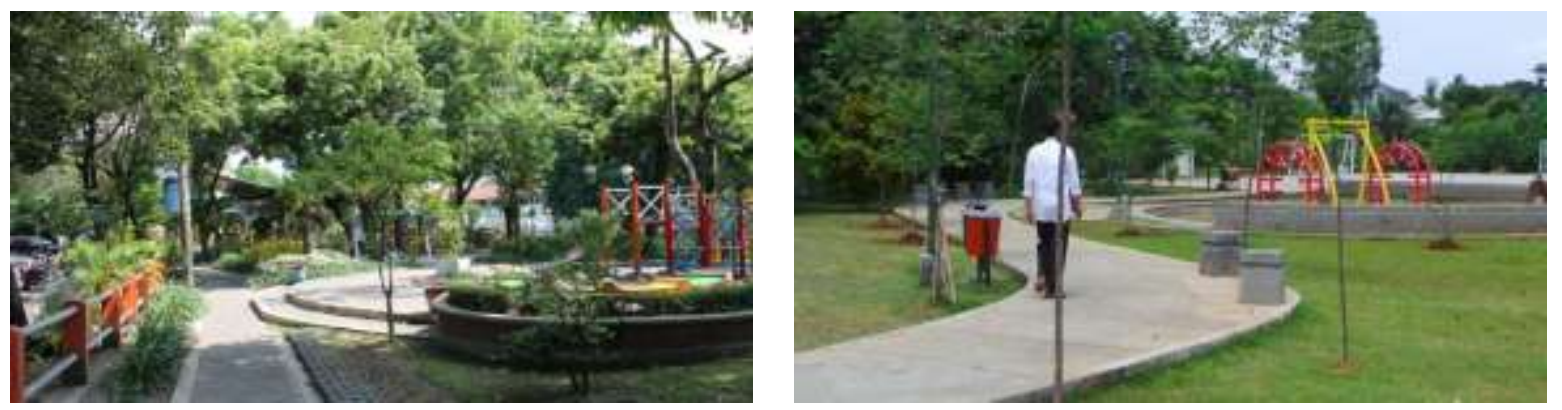

\section{Potensi Kawasan}

1. Di Kelurahan Sentul di Kota Blitar memiliki potensi sebagai industri penghasil kerajinan kayu / alat musik ketipung. Industri alat musik di Kota Blitar tersebut dapat memenuhi kebutuhan lokal di Kota Blitar sendiri dan juga untuk kebutuhan regional. Selain sebagai kawasan penghasil industri kerajinan alat musik ketipung, juga dikenal dengan industri kerajinan papan catur, mainan tradisional, industri papan catur dan asbak.

2. Kawasan rencana Embung Jatimalang dan revilalisasi DAM di Kelurahan Tanggung, berada di wilayah Kecamatan Kepanjenkidul di Kota Blitar. Kawasan tersebut merupakan kawasan perkotaan dan berada satu kecamatan dengan lokasi Makam dan Museum Bung Karno serta pasar wisata yang terletak di sekitar Makam Bung Karno (J1 Ir Soekarno). Kawasan tersebut juga berdekatan dengan potensi wisata yang lain, antara lain Istana Gebang, Kebun Rojo, Monument PETA. Kesinergisan akan terjadi antara kawasan rencana dan kawasan wisata lainnya di kecamatan Kepanjenkidul.

3. Terdapat potensi Embung Jatimalang di Kelurahan Sentul, tepatnya di aliran Kali Tanen Dukuh Jatimalang Desa Sentul Kecamatan Kepanjenkidul. Potensi tersebut merupakan potensi Sumber Daya Air yang berpeluang sebagai potensi kepariwisataan. Potensi sejenis (potensi sumber daya air) juga terdapat di Desa Tanggung dengan lokasi kecamatan yang sama. Potensi tersebut merupakan revitasisasi DAM di Desa Tanggul. Keduanya merupakan kawasan permukiman yang saling berdekatan dan dituntut untuk saling berkolaborasi dan sinergis karena memiliki potensi kepariwisataan dengan skala lokal.
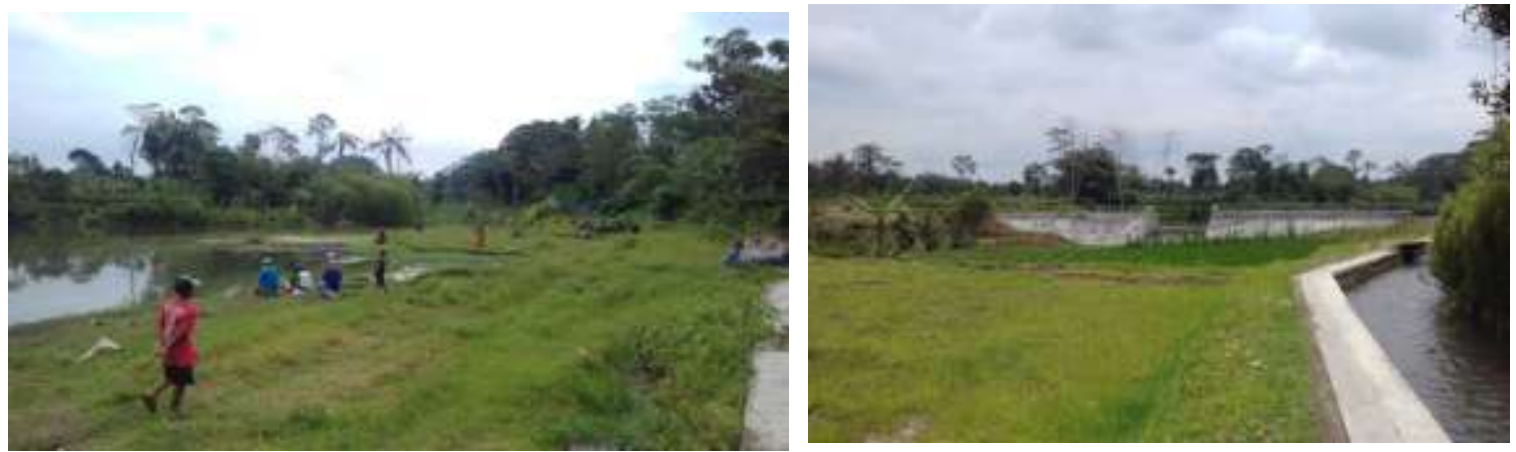

Gambar 5 : Kawasan Embung Jatimalang yang potensial sebagai Destinasi Wisata baru di Kota Blitar (Sumber : Dokumen Pribadi th 2018) 

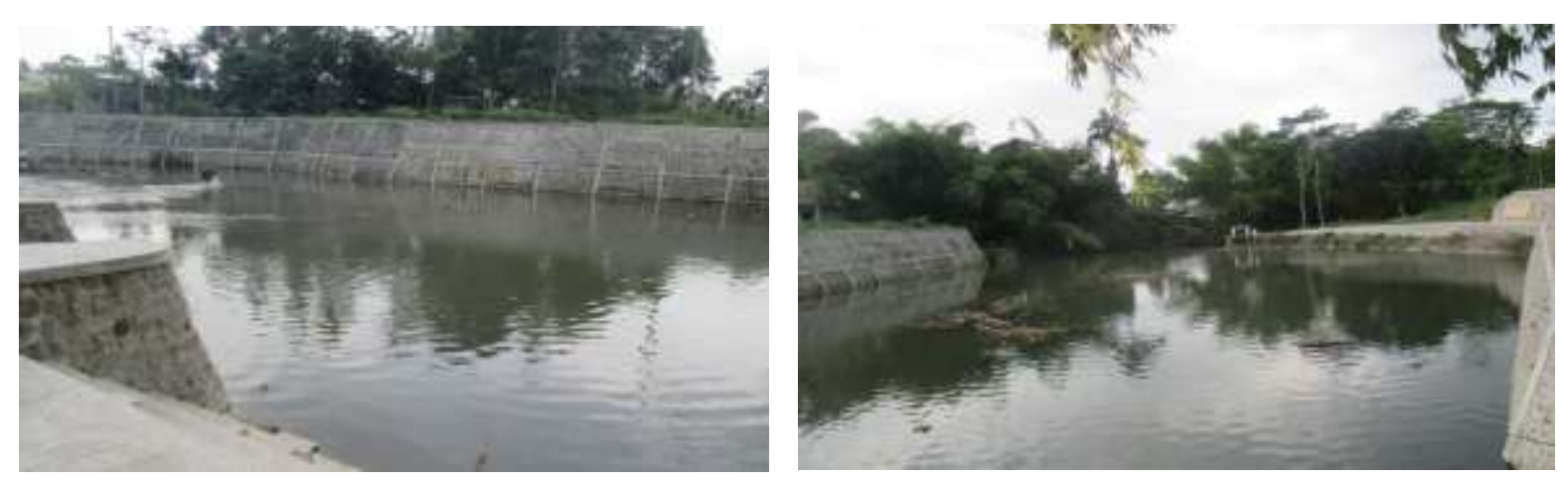

Gambar 6: Kawasan Dam Tanggung di Kelurahan Tanggung (Sumber : Dokumen Pribadi th 2018)

Pada gambar di atas terlihat bahwa lokasi embung Jatimalang dan DAM Tanggung masih belum ada perencanaan yang terkait dengan penataan kawasan permukiman yang terkait dengan kepariwisataan. Eksisting kawasan belum terolah dengan baik. Dengan adanya perencanaan penataan tersebut diharapkan kawasan embung Jatimalang dan DAM Tanggul menjadi daerah tujuan wisata baru di Kota Blitar. Beberapa alternatif yang dapat diusulkan adalah :Wahana Air di Embung Jatimalang dan Bendung Tanggung,Ruang Terbuka Hijau dan play-ground / wisata keluarga, Rencana Kawasan Outbond di Embung Jatimalang dan Bendung Tanggung, Taman dengan tema tertentu, misalnya : Taman Kali Lahar, Taman pancing, Ruang Belajar di alam terbuka, Ruang Umum/komunal / ruang pamer terbuka, Jogging track, Fasilitas foto untuk selfie, Parkir dan Fasilitas hotspot.
4. Lokasi kawasan perencanaan di sekitar embung Jatimalang dan lokasi revitalisasi DAM memiliki kemudahan aksesibilitas, sistem sirkulasi dan didukung oleh sistem utilias lingkungan yang baik.

5. Ada potensi dari perusahaan seperti PLN yang memberikan bantuan pembuatan pot ke Kelurahan Tanggung (CSR). Potensi ini bisa menjadi pemicu untuk memunculkan CSR-CSR lain dalam pembangunan masyarakat di Kelurahan Sentul dan Tanggung.

6. Di luar kawasan, sekitar embung Jatimalang dan DAM Tanggung dan berdekatan dengan kedua kelurahan, terdapat obyek wisata religi berupa Goa Maria Sendangrejo yang terletak di Kelurahan Ngadirejo Kota Blitar. Ketiga lokasi tersebut saling berdekatan dan menjadi sebuah destinasi wisata di Kecamatan Kepanjenkidul. 
Analisis Prioritas Program Rencana Pembangunan (Analisis SWOT)

\begin{tabular}{|c|c|c|}
\hline $\begin{array}{l}\text { STRATEGI } \\
\text { INTERNAL }\end{array}$ & $\begin{array}{l}\text { Kekuatan (Strength) } \\
\text { 1. Embung Jatimalang dan } \\
\text { Bendung Tanggung } \\
\text { menjadi salah satu wahana } \\
\text { perairan } \\
\text { 2. Menjadi wisata keluarga di } \\
\text { wilayah utara Blitar } \\
\text { 3. Potensi industri kendang, } \\
\text { papan catur dan mainan } \\
\text { anak. } \\
\text { 4. Potensi sebagai ruang } \\
\text { terbuka hijau }\end{array}$ & $\begin{array}{l}\text { Kelemahan (Weakness) } \\
\text { 1. Belum adanya perencanaan } \\
\text { yang detil untuk } \\
\text { pengelolaan kawasan } \\
\text { embung dan bendung. } \\
\text { 2. Belum memiliki tetenger / } \\
\text { sistem tanda } \\
\text { 3. Potensi lahan parkir } \\
\text { sempit ada transportasi } \\
\text { 4. Tidak an } \\
\text { umum yang } \\
\text { menghubungkan kawasan } \\
\text { Embung Jatimalang, } \\
\text { Bendung Tanggung dan } \\
\text { obyek wisata lain. }\end{array}$ \\
\hline $\begin{array}{l}\text { Peluang (Opportunity) } \\
\text { 1. Kota Blitar memiliki peran } \\
\text { yang cukup strategis di } \\
\text { prov. Jatim, } \\
\text { 2. Mempertahankan predikat } \\
\text { Kota Blitar sebagai Kota } \\
\text { Pariwisata pada RPJP th } \\
\text { 2005-2025 }\end{array}$ & $\begin{array}{l}\text { 1. Promosi yang intensif dan } \\
\text { terstruktur dengan didukung } \\
\text { oleh sumber daya yang } \\
\text { memadai. Salah satu cara } \\
\text { promosi adalah dengan } \\
\text { metode jemput bola, } \\
\text { promosi keluar wilayah, } \\
\text { serta dengan promosi } \\
\text { kebudayaan. } \\
\text { 2. Memperbaiki prasarana dan } \\
\text { sarana pendukung wisata di } \\
\text { Kawasan Rencana. }\end{array}$ & $\begin{array}{l}\text { 1. Membuat perencanaan } \\
\text { yang komprehensif hingga } \\
\text { DED, agar penanganan } \\
\text { menjadi tuntas dengan } \\
\text { melibatkan masyarakat. }\end{array}$ \\
\hline $\begin{array}{l}\text { Ancaman (Threats) } \\
\text { 1. Wahana air di Kota Blitar } \\
\text { sangat kurang, baik ragam } \\
\text { maupun fasilitas } \\
\text { pendukungnya. }\end{array}$ & $\begin{array}{l}\text { 1. Mendorong stakeholder } \\
\text { untuk lebih menggalakkan } \\
\text { potensi wisata di Kota } \\
\text { Blitar, khususnya untuk } \\
\text { wanana air atau wahana } \\
\text { rekreasi keluarga } \\
\text { 2. Masyarakat berinovasi } \\
\text { untuk membuat produk lain } \\
\text { sebagai alternatif dengan } \\
\text { bahan dasar kayu, agar } \\
\text { karya-karya yang dihasilkan } \\
\text { bisa semakin beragam }\end{array}$ & $\begin{array}{l}\text { 1. Membentuk jaringan } \\
\text { kelembagaan yang sinergis } \\
\text { dan memperkuat komunitas } \\
\text { masyarakat khususnya untuk } \\
\text { pengrajin di kawasan } \\
\text { rencana, }\end{array}$ \\
\hline
\end{tabular}

Sumber : Hasil Analisis

\section{Kesimpulan Dan Rekomendasi}

Berdasarkan pembahasan yang telah dilakukan pada bab-bab sebelumnya, maka kesimpulan penelitian ini adalah

1. Penelitian Rencana Pengembangan Kawasan Perumahan dan Permukiman di Kawasan Embung Jatimalang dan Bendung Tanggung merupakan pengembangan kawasan perumahan dan permukiman berbasis pariwisata. Dalam pengertian bahwa telah terjadi kolaborasi yang saling menguntungkan diantaranya, baik kawasan perumahan dan permukiman serta kawasan pariwisata. Key-word.

Dalam hal ini telah didapatkan konsep terkait pengembangan Penataan Permukiman Pendukung Wisata Sebagai Upaya Meningkatkan Daya Saing Pada Pengembangan Obyek Wisata Makam Bungkarno Kota Blitar. Pengembangan di 
sekitar kawasan Embung Jatimalang dan Bendung Tanggung diarahkan pada kawasan permukiman yang masih kosong (konsep infill kawasan), dengan konsep kawasan sekitar embung dan bendung dapat diarahkan untuk RTH, Ruang publik. Play ground, ruang olah raga, joging track, ruang duduk-duduk, tempat untuk foto / selfi, tempat kolam pancing dan parkir motor. Pada RTH di Embung Jatimalang dan Bendung Tanggung diarahkan dengan tema wisata keluarga dan wisata pancing.

2. Strategi yang dihasilkan adalah Perlunya dibentuk kelembagaan pengelolaan kawasan guna Penataan Permukiman Pendukung Wisata Sebagai Upaya Meningkatkan Daya Saing Pada Pengembangan Obyek Wisata Makam Bung Karno Kota Blitar yang merupakan representasi bersama bagi seluruh warga Kecamatan Kepanjenkidul, khususnya Kelurahan Sentul dan Tanggung. Oleh karena itu unsur-unsur yang akan masuk dalam kelembagaan tersebut adalah :

a. Stakeholder yang diwakili oleh dinas terkait di lingkungan Pemerintah Kota Blitar, misalnya : Bappeda, Dinas Perumahan Rakyat, Dinas PU dan Tata Ruang, Dinas Pertanian, Dinas Lingkungan Hidup (DLH), unsur Kecamatan dan Kelurahan

b. Tokoh Masyarakat

c. Asosiasi / Paguyuban Pengrajin

d. Karang Taruna

e. Kelompok Tani

f. Unsur-unsur lainnya di luar ketentuan di atas yang dianggap perlu.

Secara umum kelembagaan yang dibentuk memiliki tugas sebagai berikut :

Mengatur manajemen pengelolaan kawasan mulai dari tahap perencanaan, pelaksanaan, hingga pemanfaatan bersama dengan dinas terkait menyusun proposal rencana pembangunan dan pelaksanaan dengan menggunakan konsep CSR (Bappeda, Dinas Perumahan Rakyat, Dinas PUPR, DLH, DinasPertanian, Dinas Perhubungan, Dinas Paariwisata dan Pengelola Kawasan Embung Jatimalang dan Bendung Tanggung) guna Membantu melakukan pengawasan pelaksanaan konstruksimenyusun SOP untuk pelaksanaan dan pengaturan, pengawasan dan monitoring, evaluasi, operasional Embung
Jatimalang, Bendung Tanggung, Pengelolaan RTH, kolam pancing, play-ground dan parkir

1. Diperlukan promosi yang intensif dan terstruktur dengan didukung oleh sumber daya yang memadai. Salah satu cara promosi adalah dengan metode jemput bola, promosi keluar wilayah, serta dengan promosi kebudayaan.

2. Memperbaiki prasarana dan sarana pendukung wisata di Kawasan Rencana.

3. Membuat perencanaan yang komprehensif hingga DED, agar penanganan menjadi tuntas dengan melibatkan masyarakat.

4. Mendorong stakeholder untuk lebih menggalakkan potensi wisata di Kota Blitar, khususnya untuk wanana air atau wahana rekreasi keluarga.

5. Meningkatkan motifasi masyarakat agar semakin berinovasi untuk membuat produk lain sebagai alternatif dengan bahan dasar kayu, agar karya-karya yang dihasilkan bisa semakin beragam.

6. Membentuk jaringan kelembagaan yang sinergis dan memperkuat komunitas masyarakat khususnya untuk pengrajin di kawasan rencana.

7. Meningkatkan kesadaran masyarakat akan pentingnya lingkungan dan wisata berkelanjutan.

8. Bekerjasama dengan agenagen perjalanan baik yang ada di Indonesia maupun luar negeri.

9. Menyediakan serta melengkapi infrastruktur dan fasilitas wisata guna menunjang aktivitas wisatawan.

10. Membuat website khusus wisata Kota Blitar.

\section{E. Daftar Pustaka}

Agustino, Leo. 2008. Dasar-Dasar Kebijakan Publik. Bandung : PT. Alfabeta.

Dunn, William N. 2008. Analisis Kebijakan Public.Yogyakarta : PT. Hanindita.

Erwan Agus Purwanto, Dyah Ratih Sulistyastuti. 2012. Implementasi Kebijakan Publik (Konsep dan Aplikasinya di Indonesia). Yogyakarta : Gava Media.

Islamy, Irfan. 1997. Prinsip-Prinsip Kebijakan Negara.Jakarta :Buku Asara. 
Moloeng, lexy J. 2004. MetodePenelitian Kualitatif. Bandung :Rosda.

Nasution. 2003. Metode Research. Jakarta : PT. BumiAksara.

Nugroho, Riant Dr.. 2004. Kebijakan Publik Formulasi, Implementasi, dan Evaluasi. Jakarta: PT. Gramedia

-----. 2006. Kebijakan Publik Untuk Negaranegara Berkembang. Jakarta: PT. Elex Media Komputindo.

2012. Public Policy. Jakarta: PT. Elex Media Komputindo.

Nurhajati.2005. Paradigma Baru Pengembangan Usaha Kecil Menengah untuk Meningkatkan Daya Saing Ekonomi.Malang :UNISMA.

Parsolong, Harbani. 2010. Teori Administrasi Publik. Bandung : Alfabeta

Ratminto \& Atik Septi Winarsih. 2006. Manajemen Pelayanan, Cetakan I. Yogyakarta: Pustaka Pelajar

Said Zainal Abidin, 2012, Kebijakan Publik, Salemba Humanika Jakarta,

Subarsono. 2002. Analisis Kebijakan Publik (Konsep, Teori,dan Aplikasi).Yogyakarta : Pustaka Pelajar.

Sugiyono. 2007. Memahami Penelitian Kualitatif. Bandung : Alfabeta

Tachjan. 2006. Implementasi Kebijakan Publik. Bandung : TrueNorth.

Undang-Undang No. 20 Tahun 2008 Tentang Usaha Mikro, Kecil dan Menengah (UMKM) Yogyakarta : Pustaka Mahardika.

Wahab, Abdul, Solichin. 2001. Analisa Kebijakan Dari Formulasi ke Implementasi Kebijakan Negara.Bumi Aksara : Jakarta.

2002. Analisis Kebijaksanaan, Dari Formulasi $\mathrm{Ke}$ Implementasi Kebijaksanaan.Jakarta : Bumi Aksara

Winantyo, R. Dkk. 2008. Masyarakat Ekonomi ASEAN (MEA). Jakarta: PT Elex Media Komputindo Kelompok Kompas Gramedia

Yunus, HS. 2010. Metodologi Penelitian Wilayah Kontemporer. Yogyakarta: Pustaka Pelajar 